\title{
Curriculum reforms: In search of innovative models for dynamic education systems
}

\author{
Clementina Acedo
}

Published online: 18 December 2013

(C) UNESCO IBE 2013

A little over ten years ago, Cecilia Braslavsky, then director of the UNESCO International Bureau of Education (IBE) noted that the concept of the curriculum was evolving towards new approaches (Braslavsky 2001). Moving away from merely prescribing content, curricula today are incorporating more holistic dimensions. The UNESCO IBE has moved forward along this road, for curriculum involves all the processes of curriculum development, from reaching agreement among stakeholders on the main objectives of education and societal goals, to deciding which path will lead to the intended learning outcomes and associated learning experiences at various levels of education. That is, what should students learn, and why, when, and how? Today it is vital to select, and carefully structure, the relevant knowledge, competencies, and values if young people are to develop their own life plans and be proactive citizens in their own societies and in an interconnected world.

Now, after more than two decades of movements in education systems throughout the world, what stage in its evolution has the concept of curriculum reached? In this issue of Prospects, several researchers at the UNESCO Chair in Curriculum Development (UCCD) in Montreal, and their partners, attempt a collective response. They have chosen to focus their research and reflection on curriculum development, a topic necessarily embedded in complexity. In so doing, they have put together an important corpus of work, both theoretical and empirical, on the concept of the curriculum, and the various ways it is understood in the field, as well as data on some of its dimensions (Charland, Cyr, Daviau, and Simbagoye 2012; Ettayebi, Opertti, and Jonnaert 2008; Jonnaert, Ettayebi, and Defise 2009; Lafortune, Ettayebi, and Jonnaert 2007). Their support of projects for ministries of education involved in curriculum reform (in Benin, Côte d'Ivoire, Madagascar, Mauritania, Niger, Democratic Republic of the Congo, Republic of the Congo, Senegal, etc.) has enabled them to study contrasting education systems. These researchers have encountered different societies seeking the forms of curriculum that are best suited to their local situations and their societal needs for education and training.

C. Acedo (ه)

UNESCO International Bureau of Education, P.O. Box 199, 1211 Geneva 20, Switzerland

e-mail: c.acedo@unesco.org 
One can engage with curricular studies through multiple entry points. These points are distributed among the various levels of a curriculum, which Keeves (1992) calls the intended curriculum, the implemented curriculum, and the achieved curriculum. He follows on the work of Schriven (1967), who sees them as existing in a hierarchy but also being fairly homogeneous. Current curriculum researchers move well beyond this theorizing (Connelly 2007; Georgescu 2007; Schiro 2008). They show that the hierarchy and homogeneity are relative, but also that the same curriculum can have many possible entry points.

The present thematic issue takes its place within an effervescence of recent curricular studies. It opens up the debate to include a series of actors in education who are working on curricula at various levels, often on different continents. Rather than addressing either the homogeneity or the distance between Keeves's three curricular levels, the authors in this special issue illustrate that the levels are moving towards each other. Each article addresses curricular issues through one of the possible entry points in this complex process. Thus, this special issue offers a varied contribution to the contemporary debate on curriculum development.

First, Philippe Jonnaert and Geneviève Therriault provide a framework for all of the studies in this issue, indicating how each article contributes to our better understanding of curriculum development. The authors broaden their approach, progressively extracting the concept of the curriculum from models that are liable to undermine its dynamic and open nature.

Jean-Philippe Ayotte-Beaudet analyses definitions of competence in French-language studies. He selected the most widely quoted authors and developed an analytical table to compare their definitions. Seeking to identify a common semantic base for these definitions, he instead finds a plurality of definitions which ultimately converge on a single point: they all refer to cognitive resources. In other words, knowledge remains the one common point of all the definitions of competence that he analysed.

Roger-François Gauthier describes a study of a curriculum reform that adopted the competency-based approach as the organizing principle for education programmes. He makes various observations on the situation of these reforms in five sub-Saharan African countries.

Geneviève Therriault and Léon Harvey decode the effects that a reform of teacher training has on the students' epistemological beliefs, and how those beliefs relate to the students' knowledge. They developed an interesting methodology to analyse this dimension of the curriculum: adapting and validating a questionnaire on the personal epistemology of students and applying it to a sample of preservice teachers, who are students at the Université du Québec à Rimouski. Their data analysis reveals the diversity of epistemological postures that students develop during their training. These conceptions also vary depending on the students' training context: they answered differently when they were in a university course training them in their discipline, and when they were in their practical training in the secondary classroom.

Patrick Charland and Stéphane Cyr analyze a curricular approach adopted in the Republic of Niger for basic education. They focus on the methodology used to develop situations based on a bank of classes of situations assembled in the field, and more specifically on the formulation of education programmes for mathematics based on a situated approach.

Rosette Defise chooses another entry point into the curriculum: the training of teacher trainers. Considering the major role that teachers play in the process of implementing curriculum reform, she describes how, when working on concepts such as learning 
communities and class management, she has managed to change teaching habits and practices by integrating the pedagogical and teaching innovations set out in a curriculum reform.

Daniela Furtuna addresses the question of curriculum from the viewpoint of assessment. She describes a methodology she developed to build up an items bank for constructing mathematics and reading tests for students completing primary education. What makes her work so original is the variety of tools she has developed: based on these items, educators can assess the cognitive attainments of students who are following a curriculum reform that focuses on developing competencies.

Thus, by looking at curriculum through a variety of approaches, and in a variety of situations, these authors offer valuable insights into the current and crucial issues surrounding it, and thus contribute to the contemporary debate on curriculum development and reform.

\section{References}

Braslavsky, C. (2001). Tendances mondiales et développement des curricula [Global trends and curriculum development]. Lecture given at the Journées internationales sur les politiques nationales d'éducation et de formation, Brussels, 9-12 May. Brussels: Association Francophone d'Éducation Comparée (AFEC). http://www.er.uqam.ca/nobel/cudcu/publication/ref/20braslavsky.pdf.

Charland, P., Cyr, S., Daviau, C., \& Simbagoye, A. (Eds.) (2012). Écoles en mouvement et réformes: enjeux, défis et perspectives - États des lieux et questions curriculaires [Schools in movement and under reform: Issues, challenges and perspectives-The present situation and curricular questions]. Brussels: De Boeck Université.

Connelly, F. M. (Ed.) (2007). The Sage handbook of curriculum and instruction. London: Sage.

Ettayebi, M., Opertti, R., \& Jonnaert, P. (Eds.) (2008). Logique de compétences et développement curriculaire. Débats, perspectives, alternatives [The logic of competencies and curriculum development: Debates, perspectives, alternatives]. Paris: L'Harmattan.

Georgescu, D. (2007). Introduction to the Open File: Curriculum developers facing education reform challenges. Prospects, 144(4).

Jonnaert, P., Ettayebi, M., \& Defise, R. (2009). Curriculum et compétences. Un cadre opérationnel [Curriculum and competencies: An operational framework]. Brussels: De Boeck Université.

Keeves, J. (1992). Methodology and measurement in international and educational surveys. London: Pergamon Press.

Lafortune, L., Ettayebi, M., \& Jonnaert, P. (Eds.) (2007). Observer les réformes en éducation [Observing education reforms]. Québec: Presses de l'Université du Québec.

Schriven, M. (1967). The methodology of evaluation. AERA Series on Curriculum Evaluation. Chicago: Rand McNally.

Schiro, M. S. (2008). Curriculum theory: Conflicting visions and enduring concerns. London: Sage. 